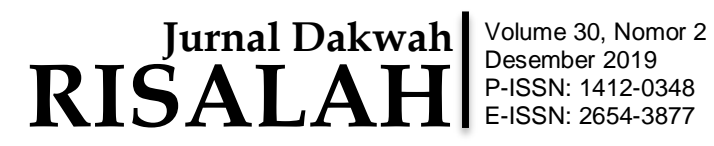

DOI: $10.24014 /$ jdr.v30i2.8538

\title{
KONTRIBUSI DAKWAH DALAM AKTUALISASI NILAI-NILAI EKONOMI ISLAM PADA MASYARAKAT MELAYU PEDESAAN
}

\author{
Ginda Harahap ${ }^{1}$ \\ ${ }^{1}$ Universitas Islam Negeri Sultan Syarif Kasim Riau \\ Email: ginda@uin-suska.ac.id
}

\author{
Kata kunci \\ Dakwah, Ekonomi \\ Islam, \\ Melayu
}

\begin{abstract}
Abstrak
Peranan dakwah semakin strategis saat ini untuk menunjang aktualisasi nilai-nilai ekonomi Islam di tengah-tengah masyarakat Melayu. Dakwah merupakan kegiatan yang sangat aplikatif pada masyarakat muslim untuk mengajak, memanggil, dan mendorong umat Islam untuk mengaplikasikan ajaran Islam dalam kehidupan sehari-hari. Penelitian ini dilakukan untuk memperoleh informasi tentang kontribusi positif kegiatan dakwah sebagai instrumen Islamisasi dalam pewarisan nilai-nilai ekonomi Islam etnis Melayu Rokan Hulu, dan aplikasinya dalam transaksi ekonomi masyarakat Melayu kontemporer. Penelitian dilakukan di Kecamatan Rambah di mana 90\% masyarakat mayoritas etnis Melayu. Penelitian ini menggunakan pendekatan kuantitatif dengan penyebaran angket untuk pengumpulan data. Teknik analisis data menggunakan Korelasi Koefisien Kontingensi. Berdasarkan hasil analisis ditemukan bahwa masih terdapat kontribusi aktivitas dakwah dalam upaya aktualisasi nilai-nilai ekonomi Islam tapi tidak cukup signifikan.
\end{abstract}

\begin{abstract}
The role of dakwah nowadays strategically supports the actualization of Islamic economy values in Malay society. Dakwah is aplicable activity in persuading, calling, and motivating muslims to implement Islamic teaching in daily life. This research was conducted to obtain information about the positive contribution of dakwah activities as an instrument of Islamization in the inheritance of the Islamic economic values of the Rokan Hulu Malay ethnic group, and its application in economic transactions in contemporary Malay society. The study was conducted in Rambah District, where 90\% of the majority was Malay ethnic. This research used quantitative approach by spreading quetioners in collecting data. The data analysis technique used Contingency Coefficient Correlation. Based on the results of the analysis, it was found that there was contribution of dakwah activities in effort to actualize Islamic economic values but it was not significant.
\end{abstract}




\section{Pendahuluan}

Peranan dakwah semakin strategis saat ini untuk menunjang aktualisasi nilai-nilai ekonomi Islam di tengah masyarakat Melayu. Sebagaimana diketahui bahwa dakwah merupakan kegiatan yang sangat aplikatif bagi masyarakat muslim untuk mengajak, memanggil, dan mendorong umat Islam untuk mengaplikasikan ajaran Islam (Hatimah\&Kurniawan, 2017: 3), termasuk nilai-nilai ekonomi Islam dalam kehidupan sehari-hari.

Kecamatan Rambah merupakan salah satu kecamatan di Kabupaten Rokan Hulu yang terdiri dari 13 desa dan 1 kelurahan. Penduduk Kecamatan Rambah terdiri dari berbagai kelompok etnis, di mana etnis Melayu merupakan mayoritas. Selain etnis Melayu juga ada etnis pendatang yang sudah menetap yaitu dari suku Jawa, Mandailing, Minang, dan lain sebagainya.

Kegiatan dakwah telah lama dilakukan oleh masyarakat Melayu di Kabupaten Rokan Hulu karena dakwah merupakan instrumen penting untuk membelajarkan masyarakat Melayu dengan ajaran-ajaran Islam. Seperti yang telah dijelaskan sebelumnya, masyarakat Melayu Islam adalah sebuah identitas etnis dan acuan sistem nilai tertinggi di atas kebudayaan, adat, dan tradisi.

Semarak kegiatan dakwah di Rokanhulu telah banyak dilakukan di masyarakat perkotaan seperti Ujung Batu, Dalu-Dalu, dan Pasir Pengaraian sendiri sebagai ibukota kabupaten. Masyarakat Melayu melakukan kegiatan dakwah secara kontinu untuk melestarikan pengamalan ajaran Islam dalam berbagai aspek di masyarakat, termasuk aspek ekonomi Islam.

Warisan sejarah Melayu sangat berharga yang ditandai oleh kemajuan Melayu dalam aspek peradaban dan perdagangan di masa lalu. Ini tidak lepas dari Islam sebagai identitas yang telah merasuk ke dalam sukma peradaban dan menjelma menjadi semangat dan ruh yang mendorong kemajuan peradaban Melayu dalam berbagai aspek. Akan tetapi menurut U.U. Hamidy, Islamisasi budaya Melayu bergerak lamban dan bahkan pengamalan ajaran Islam di masyarakat terkesan didistorsi oleh sistem nilai ekonomi yang lain atau karena ketidaktahuan masyarakat yang bersangkutan.

Penelitian ini dilakukan untuk menemukan apakah kegiatan dakwah yang dilakukan tersebut memiliki kontribusi positif sebagai instrumen Islamisasi dalam pewarisan nilai-nilai ekonomi Islam yang menjadi sistem nilai masyarakat Melayu dan dapat diaplikasikan oleh masyarakat Melayu kekinian (kontemporer). Penelitian ini mengkaji permasalahan menyangkut kontribusi yang diberikan oleh aktivitas dakwah terhadap implementasi nilai-nilai ekonomi Islam di tengah masyarakat Melayu di Kecamatan Rambah Rokan Hulu. Untuk itu permasalahan tersebut dirinci dalam formula pertanyaan sebagai berikut: Apa saja bentuk nilai-nilai ekonomi Islam yang sudah dilaksanakan oleh masyarakat Melayu dalam kehidupan sehari-hari? Bagaimana kontribusi aktivitas dakwah dalam upaya implementasi nilai-nilai ekonomi Islam pada masyarakat Melayu di Kecamatan Rambah Kabupaten Rokan HuIu. 
Istilah Melayu mempunyai banyak arti dalam berbagai konteks yang berbeda. Ditinjau dari aspek sosial budaya yang luas, istilah Melayu mencakup berbagai etnis yang tinggal dan hidup di Nusantara. Melayu yang meliputi Semenanjung Melayu (Malaysia) dan ribuan pulau yang menjadi Indonesia, Filipina, Brunei Darussalam, dsb (Ali, 1985: 5). Seorang Melayu ditinjau dari konteks religius adalah orang muslim karena itu ungkapan "masuk Melayu" di Malaysia dan sebagian orang Indonesia memahaminya adalah masuk Islam.

Jika lebih dikhususkan lagi, istilah Melayu adalah konsep yang menunjukkan satu etnis yang beragama Islam, berbahasa Melayu, dan beradat istiadat Melayu. (Suwardi MS, 1991: 28). Islam diterima dan menjadi ciri khusus dalam adat istiadat dan bahasa Melayu.

Keterkaitan Islam dengan Melayu sebagai etnis dan budaya secara historis diperkirakan mulai tahun 1295 M. Islam masuk ke jajaran politik Melayu secara formal diperkirakan tahun 1414 M ketika raja Melaka Prameswara memeluk Islam, kemudian beliau dikenal dengan nama Sultan Muhammad Iskandar Syah. Hubungan dagang dan budaya maupun letak geografis yang dekat antara Melaka dengan Riau merupakan faktor yang mempengaruhi suksesnya islamisasi kerajaan-kerajaan Riau seperti Kerajaan Riau Lingga, Kerajaan Siak, dan lain sebagainya. Sementara agama Islam tentu sudah sampai ke dunia Melayu jauh Iebih awal dari itu (Hamidy, 1999: 6).

Persentuhan Islam dengan Melayu telah memberi warna dan corak tersendiri bagi kehidupan orang Melayu. Islam telah menjadi bagian penting dalam kehidupan orang Melayu. Bagi Melayu, Islam menjadi anutan dalam peri kehidupan masyarakat, Islam menjadi sistem nilai dalam politik, sosial, ekonomi, dan budaya. Islam telah menjadi identitas Melayu. Deliar Noor menjelaskan bahwa kata "masuk Melayu" diartikan dengan masuk Islam. Begitulah Islam telah menjadi identitas Melayu dan menunjukkan bahwa Islam sangat erat dan bahkan identik dengan Melayu.

Dalam konteks hubungan antara fakta historis dengan realitas Melayu kekinian sangat perlu mendapat perhatian karena kemajuan dan kesuksesan Melayu dalam rentang sejarahnya tidak dapat dilepaskan sejak persentuhan Melayu dengan Islam, atau sejak Islam menjadi ruh bagi orang Melayu. Ini berarti Islam telah menjadi fondasi penting peradaban Melayu sampai saat ini. Oleh sebab itu, dapat diasumsikan bahwa memajukan peradaban Melayu kekinian hendaknya dikembalikan pada prinsip-prinsip pokok ruh dan semangat Melayu, termasuk dalam pengembangan ekonomi masyarakat Melayu. Secara historis nilai-nilai ekonomi Islam telah menjadi bagian penting dan tidak terpisahkan dari sistem nilai masyarakat Melayu dalam memajukan ekonomi masyarakat Melayu.

Sejak Indonesia zaman kolonial sampai merdeka, umat Islam telah dijejali dengan pemikiran dan budaya-budaya Barat yang secara bertahap mendesak nilai-nilai Islam, yang dalam konteks ekonomi dikenal dengan Kapitalisme. Meskipun tidak diakui secara 
resmi, nilai-nilai Kapitalisme telah menjadi bagian penting dalam sistem perekonomian Indonesia selama ini.

Saat ini telah banyak muncul kajian tentang sistem ekonomi alternatif menggantikan sistem ekonomi konvensional semacam sistem ekonomi kapitalisme (Iskandar, 2017: 256). Perkembangan pemikiran ekonomi Islam akhir-akhir ini yang semakin marak dan intensif dikaji dari berbagai aspek, sejalan dengan kegagalan kapitalisme, telah memunculkan kembali nilai-nilai Islam dalam aspek ekonomi. Hal ini sekaligus menjadi peluang dalam kemajuan peradaban Melayu, khususnya dalam aspek ekonomi. Ini sejalan dengan visi yang menjadikan Riau sebagai pusat perdagangan dan peradaban Melayu.

Secara teoritis, terdapat 4 komponen nilai-nilai ekonomi Islam yaitu: nilai rabbaniyah, nilai akhlak/moral, nilai kemanusiaan, nilai pertengahan (Afzalurrahman, 1992: 181). Kedekatan Islam dengan Melayu telah menjadikan nilai-nilai ini bagian penting dari konten peradaban ekonomi etnis Melayu. Indikasi penting untuk pernyataan ini adalah ditemukannya dalam tradisi Melayu ungkapan misalnya, harta benda itu yang penting ialah berkahnya bukan jumlahnya. Kemudian, harta yang diperoleh dengan jalan curang (tidak halal) akan mendatangkan bencana, mencari harta sekadar yang diperlukan. Jangan sampai mati dalam keadaan berutang. Ungkapan arif dan bijak yang demikian jelas muncul dari islamisasi pandangan hidup orang Melayu dalam aspek ekonomi.

\section{Metode}

Penelitian ini adalah penelitian kuantitatif. Penelitian dilakukan di Kecamatan Rambah Kabupaten Rokan Hulu. Luas Kecamatan Rambah adalah 396,61 Km² didiami oleh mayoritas etnis Melayu. Kecamatan ini terdiri dari 1 kelurahan dan 13 desa. Dari hasil wawancara yang dilakukan dengan pihak Kecamatan Rambah, diketahui bahwa terdapat 4 desa yang berpenduduk hampir 90\% etnis Melayu yaitu Desa Koto Tinggi, Desa Pematang Berangan, Desa Rambah Tengah Utara, dan Desa Rambah Tengah Hilir. Sementara Desa Babussalam sudah banyak bercampur dengan suku-suku pendatang.

Atas pertimbangan finansial, waktu, dan tenaga, peneliti menggunakan area probability sampling dan menetapkan 2 desa dari 4 desa yang menjadi unit populasi penelitian yaitu Desa Pematang Berangan dan Desa Rambah Tengah Utara. Jumlah penduduk pada dua desa ini sebesar 12509 jiwa, dengan rincian 7736 orang penduduk Desa Pematang Berangan dan 4773 orang penduduk Desa Rambah Tengah Utara. Penduduknya $90 \%$ di antaranya mayoritas Melayu atau kurang lebih 11.250 orang. Meskipun tidak diketahui secara tepat berapa jumlah orang dewasa di kedua desa tersebut, karakteristik desa yang cukup homogen secara metodologi tentu dapat dipertimbangkan bahwa populasi penelitian adalah seluruh etnis Melayu yang dewasa dan berdomisili di Desa Pematang Berangan dan Desa Rambah Tengah Utara. 
Peneliti mengambil sampel sebesar 75 orang/jiwa yang didistribusikan pada unit populasi sebesar 44 orang di Desa Pematang Berangan dan 31 orang di Desa Rambah Tengah Utara. Besaran sampel 75 orang diperkirakan cukup representatif, mengingat derajat dan karakteristik homogenitas populasi masyarakat desa cukup tinggi. Penetapan dilakukan dengan random sampling. Karena itu teknik yang dipakai dalam pengambilan sampel adalah area probability random sampling.

Teknik pengumpulan data dilakukan dengan penyebaran angket. Data yang telah dikumpulkan dianalisis dengan teknik analisis data Korelasi Koefisien Kontingensi dengan rumus:

$$
C=\sqrt{\frac{X^{2}}{X^{2}+N}}
$$

Untuk memperoleh Koefisien Korelasi C dihitung Phi Kuadrat dengan rumus:

$$
\mathbf{X}^{2}=\frac{\sum\left(\mathrm{f}_{\mathrm{O}}-\mathrm{f}_{\mathrm{t}}\right)}{\mathrm{f}_{\mathrm{t}}}
$$

Untuk interpretasi data diubah harga Koefisien Kontingensi (C) menjadi phi $(\phi)$ dengan rumus:

$$
\phi=\frac{C}{\sqrt{1-C^{2}}}
$$

\section{Hasil dan Pembahasan}

Kecamatan Rambah merupakan kecamatan yang dihuni 90\% oleh etnis Melayu, yang berbahasa Melayu, berkebudayaan Melayu, dan bertradisi melayu. Penelitian ini dilakukan untuk mengetahui kontribusi yang dapat dilakukan oleh kegiatan dakwah dalam upaya implementasi nilai-nilai ekonomi Islam yang selama ini telah menjadi bagian dari sistem nilai masyarakat Melayu.

Oleh karena itu, variabel yang diteliti adalah kontribusi kegiatan dakwah sebagai variabel $\mathrm{X}$ dan implementasi nilai-nilai ekonomi Islam sebagai variabel Y. Untuk memperoleh data pada kedua variabel penelitian mengambil subjek sebanyak 75 orang yang bertindak sebagai sampel yang diperkirakan cukup representatif mengingat derajat homogenitas populasi masyarakat desa cukup tinggi.

Pengukuran kontribusi aktivitas dakwah terhadap aktualisasi nilai-nilai ekonomi Islam pada masyarakat Melayu di Kecamatan Rambah menggunakan 4 indikator untuk 
variabel kontribusi dakwah dan 5 indikator untuk variabel aktualisasi nilai-nilai ekonomi Islam.

Data yang telah dikumpulkan kemudian disajikan dalam beberapa tabel distribusi frekuensi berikut ini:

Tabel 1. Tabel Rekapitulas Pendapat Masyarakat tentang

Kontribusi Aktivitas Dakwah

\begin{tabular}{clccccc}
\hline No & Aspek yang & \multicolumn{5}{c}{ Alternatif Jawaban } \\
\cline { 3 - 7 } & Ditanyakan & S.baik & Baik & K. Baik & T. Baik & Jumlah \\
\hline 1 & Kredibilitas dai & 30 & 174 & 89 & 7 & 300 \\
& & $10 \%$ & $58 \%$ & $29,7 \%$ & $2,3 \%$ & $100 \%$ \\
\hline 2 & Materi ceramah tentang & 25 & 89 & 132 & 54 & 300 \\
& ekonomi Islam & $8,3 \%$ & $29,7 \%$ & $44 \%$ & $18 \%$ & $100 \%$ \\
\hline 3 & Metode dakwah dalam & 9 & 69 & 67 & 5 & 150 \\
& ceramah ekonomi Islam & $6 \%$ & $46 \%$ & $44,7 \%$ & $3,3 \%$ & $100 \%$ \\
\hline 4 & Sumber informasi nilai- & 26 & 34 & 61 & 29 & 150 \\
& nilai ekonomi Islam & $17,3 \%$ & $22,7 \%$ & $40,7 \%$ & $19,3 \%$ & $100 \%$ \\
\hline \multirow{2}{*}{} & Jumlah & 90 & 366 & 349 & 95 & 900 \\
& & $10 \%$ & $40,7 \%$ & $38,8 \%$ & $10,5 \%$ & $100 \%$ \\
\hline
\end{tabular}

Sumber: Hasil Penyebaran Angket

Terkait dengan kontribusi aktivitas dakwah ada sebanyak 4 poin penting yang dilakukan pengkajian yaitu kredibilitas dai, materi ceramah tentang ekonomi Islam, metode dakwah yang digunakan, dan sumber informasi pengetahuan masyarakat tentang nilai-nilai ekonomi Islam.

Poin-poin penting dalam kajian kredibilitas dai yaitu: (1) Kompetensi dai yang diundang masyarakat untuk ceramah; (2) Kompetensi keilmuan dai; (3) Relevansi profesi dai dengan perbuatan dan (4); Relevansi perkataan dengan perbuatan. Keempat komponen ini menggambarkan kredibilitas dai yang meliputi ethos, phatos, logos, yang terintegrasi dalam kepribadian seorang mubalig. Data dari keempat komponen ini sebagaimana dalam tabel rekapitulasi di atas, ditemukan bahwa sebanyak 174 jawaban (58\%) baik, tapi ditemukan juga 89 jawaban atau setara dengan 29,7\% berpendapat kurang baik. Informasi yang diperoleh dari gambaran persentase ini menunjukkan bahwa terdapat suatu kondisi yang bermasalah (trouble) dalam kepribadian seorang dai yang dapat mengurangi efek positif secara maksimal dari kegiatan dakwah yang dilakukan. Ketika dilakukan pendalaman, diketahui bahwa dari perspektif kredibilitas dai, faktor trouble yang dimaksudkan terkait dengan relevansi profesi dai dengan perilaku dan kurang linearnya antara perkataan dan perilaku dai sendiri. Pada sisi kompetensi keilmuan seorang dai tidak dipersoalkan oleh masyarakat.

Poin kedua yang cukup penting untuk diuraikan berkenaan dengan konten (materi) ceramah yang disampaikan pada kegiatan wirid (dakwah) yang dilakukan. Titik 
sentral pembahasan dalam aspek ini adalah pendapat dan penilaian masyarakat tentang materi ekonomi Islam, nilai-nilai perilaku dalam kegiatan ekonomi, pengetahuan responden tentang nilai-nilai ekonomi Islam, manfaat infak sedekah dan aktualisasinya di tengah masyarakat. Dari data ini diperoleh informasi bahwa 132 jawaban atau sama dengan $44 \%$ kurang terkait dengan ekonomi Islam, sementara terdapat pula skor nilai 54 jawaban atau $18 \%$ yang menunjukkan bahwa isi materi itu tidak terkait dengan ekonomi Islam. Meskipun demikian, masih terdapat frekuensi sebesar 89 jawaban yang mengisyaratkan bahwa materi dakwah terkait dengan ekonomi Islam. Data ini memberikan pemahaman bahwa konten materi ekonomi Islam masih kurang maksimal disampaikan oleh ustaz dalam kegiatan pengajian.

Metode penyampaian materi dalam kegiatan dakwah menjadi hal penting yang selanjutnya diteliti. Titik awalnya adalah penggunaan metode ceramah, diskusi dan tanya jawab, dan bagaimana menempatkan jemaah peserta didik dalam proses dakwah. Frekuensi dalam tabel di atas menginformasikan bahwa penilaian masyarakat tentang hal ini positif sebesar 69 jawaban atau 46\%, sementara jawaban yang mengatakan kurang baik (kurang positif) sebesar 67 jawaban atau 44,7\%. Terdapat frekuensi atau persentase yang seimbang tentang penilaian masyarakat mengenai pemanfaatan metode dalam kegiatan dakwah. Informasi yang ditemukan mengisyaratkan bahwa trouble sebagai penyebab kurang positifnya penilaian masyarakat tentang metode dakwah, terkait dengan mubalig kurang memberikan ruang dan kesempatan bertanya kepada jemaah.

Ketika ditanyakan dari mana sumber informasi pengetahuan mereka tentang kegiatan-kegiatan ekonomi Islam, diperoleh jawaban yang kurang baik sebesar 61 jawaban atau 40,7\% diperoleh melalui media cetak, dan terdapat 34 responden atau $22,7 \%$ menjawab mereka peroleh dari brosur-brosur ekonomi. Tidak terdapat informasi yang menyatakan bahwa informasi tentang kegiatan ekonomi Islam mereka peroleh dari kegiatan-kegiatan dakwah yang dilakukan.

Berdasarkan akumulasi jawaban yang diperoleh tentang variabel aktivitas dakwah dan relevansinya dengan upaya aktualisasi nilai-nilai ekonomi Islam sebagaimana dalam tabel rekapitulasi frekuensi di atas, dapat dijelaskan bahwa terdapat kesimbangan persentase antara sangat baik dengan kurang baik dan tidak baik. Hal ini menunjukkan bahwa pada aspek variabel aktivitas dakwah sendiri dinilai baik sebesar 40,7 \%. Sementara pada kategori kurang baik terdapat nilai persentase sebesar 38,8\%, artinya secara kualitatif terdapat penilaian masyarakat bahwa aktivitas dakwah itu berjalan baik, meskipun belum berjalan dengan maksimal.

Data tentang aktualisasi nilai-nilai ekonomi Islam yang digunakan oleh masyarakat dalam kehidupan sehari-hari sesuai dengan jawaban dalam tabel distribusi frekuensi disajikan dalam tabel berikut ini: 
Tabel 2. Rekapitulasi Pendapat Masyarakat tentang

Pelaksanaan Nilai-Nilai Ekonomi Islam

\begin{tabular}{|c|c|c|c|c|c|c|}
\hline \multirow[t]{2}{*}{ No } & \multirow{2}{*}{$\begin{array}{l}\text { Aspek yang } \\
\text { Ditanyakan }\end{array}$} & \multicolumn{5}{|c|}{ Alternatif Jawaban } \\
\hline & & S.baik & Baik & K. Baik & T. Baik & Jumlah \\
\hline \multirow[t]{2}{*}{1} & Pemahaman masyarakat & 9 & 69 & 71 & 1 & 150 \\
\hline & terhadap materi dakwah & $6 \%$ & $46,3 \%$ & $47,3 \%$ & $1,3 \%$ & $100 \%$ \\
\hline \multirow[t]{2}{*}{2} & Pembayaran zakat & 45 & 97 & 8 & - & 150 \\
\hline & $\begin{array}{l}\text { sebagai institusi } \\
\text { ekonomi Islam }\end{array}$ & $30 \%$ & $64,7 \%$ & $5,3 \%$ & & $100 \%$ \\
\hline \multirow[t]{2}{*}{3} & Pengeluaran infak & 4 & 32 & 81 & 33 & 150 \\
\hline & $\begin{array}{l}\text { sebagai institusi } \\
\text { ekonomi Islam }\end{array}$ & $2,7 \%$ & $21,3 \%$ & $54 \%$ & $22 \%$ & $100 \%$ \\
\hline \multirow[t]{2}{*}{4} & Sikap boros dan bunga & 54 & 157 & 82 & 7 & 300 \\
\hline & $\begin{array}{l}\text { bank dalam pandangan } \\
\text { masyarakat }\end{array}$ & $18 \%$ & $52,3 \%$ & $27,3 \%$ & $2,33 \%$ & $100 \%$ \\
\hline \multirow[t]{3}{*}{5} & Pendapat masyarakat & 42 & 65 & 38 & 5 & 150 \\
\hline & $\begin{array}{l}\text { tentang relevansi } \\
\text { dakwah dengan } \\
\text { pengamalan Islam }\end{array}$ & $28 \%$ & $43,3 \%$ & $25,3 \%$ & $3,3 \%$ & $100 \%$ \\
\hline & Jumlah & $\begin{array}{c}154 \\
171 \%\end{array}$ & $\begin{array}{c}420 \\
467 \%\end{array}$ & $\begin{array}{c}280 \\
311 \%\end{array}$ & $\begin{array}{c}46 \\
51 \%\end{array}$ & $\begin{array}{c}900 \\
100 \%\end{array}$ \\
\hline
\end{tabular}

Sumber: Hasil Penyebaran Angket

Deskripsi yang terdapat dalam tabel rekapitulasi di atas memberi informasi penting tentang aktualisasi nilai-nilai ekonomi Islam dalam transaksi ekonomi masyarakat etnis Melayu. Indikator-indikator utama yang menjadi kajian adalah: (1) Pemahaman masyarakat terhadap materi ekonomi Islam dalam ceramah yang disampaikan; (2) Pembayaran zakat sebagai realisasi insititusi ekonomi Islam; (3) Pengeluaran infak sebagai realisasi aktualisasi ekonomi Islam; (4) Sikap boros dan bunga bank yang harus dihindari karena bertentangan dengan nilai ekonomi islam; (5) Pendapat masyarakat tentang dampak ceramah dengan pelaksanaan nilai-nilai ekonomi Islam.

Poin pertama berkaitan dengan pemahaman masyarakat terhadap materi ceramah yang disampaikan oleh mubalig dalam kegiatan dakwah. Subpertanyaannya dalam poin ini terkait dengan pemahaman terhadap isi ceramah dan pemahaman ekonomi Islam melalui ceramah ustaz. Frekuensi dan persentase yang diperoleh untuk indikator ini sebesar 71 jawaban atau 47,3\% menjawab kurang baik dan sebesar 69 jawaban atau $46 \%$ menjawab baik maknanya adalah berdasarkan pada tabel nomor 2 tersebut 
diperoleh informasi bahwa masyarakat (responden) kurang memahami isi ceramah mubalig/mubaligah tentang materi ekonomi Islam.

Pembayaran zakat sebagai realisasi institusi ekonomi Islam merupakan indikator kedua yang ditanyakan datanya kepada masyarakat. Subpertanyaan untuk indikator ini aktivitas membayar zakat oleh masyarakat dan ketepatan asnaf tempat membayar zakat oleh masyarakat. Dari data yang diperoleh, ditemukan angka frekuensi sebesar 97 $(64,7 \%)$ responden menjawab baik, dan 45 (30 \%) menjawab sangat baik yang memiliki arti bahwa masyarakat memang memanfaatkan instrumen zakat sebagai bagian dari transaksi ekonomi dalam Islam. Dalam hal ini masyarakat aktif mengeluarkan zakatnya dan sekaligus mengeluarkan zakat kepada mustahik yang tepat.

Pengeluaran infak dan sedekah sebagai bagian dari aktualisasi transaksi ekonomi Islam ditanyakan kepada masyarakat, dengan subpertanyaan: apakah masyarakat aktif mengeluarkan infak/sedekah sebagai wujud dari aktualisasi nilai-nilai ekonomi Islam dan sekaligus memilih tempat berinfak yang tepat? Data untuk indikator ini diperoleh sebesar $81 \%$ atau 54\% responden menjawab kurang baik, dan ditemukan sebesar 33 orang atau $22 \%$ responden menjawab tidak baik, sementara itu ditemukan juga jawaban sebesar 32 orang atau 21,3\% yang menjawab baik. Berdasarkan data pada indikator ini menunjukkan bahwa pada umumnya masyarakat kurang aktif dalam mengeluarkan infak dan sedekah, walaupun juga cukup banyak masyarakat yang aktif dan rajin bersedekah, dan memilih tempat mengeluarkan sedekah yang tepat sesuai dengan peruntukan sedekah maupun infak.

Indikator ketiga yang ditanyakan pada masyarakat etnis Melayu adalah tentang aktualisasi nilai-nilai ekonomi Islam ini adalah pendapat masyarakat tentang sikap dan perilaku boros dalam membelanjakan harta yang ia miliki dan sikap serta perilaku mereka tentang bunga bank maupun alasan mereka mau menerima dan membungakan uang. Data yang diperoleh menunjukkan bahwa, 157 orang atau 52,3\% menjawab baik, dan 54 orang atau 18\% menjawab sangat baik, dalam hal ini sikap boros dan membungakan uang kurang disukai oleh masyarakat melakukannya. Namun disamping itu masih ada responden yang menjawab sebesar 82 orang atau 27,3\% kurang baik. Hal ini dapat dimengerti bahwa terdapat anggota masyarakat yang menganggap membungakan uang tidak menjadi masalah.

Pertanyaan terakhir terkait dengan pendapat responden tentang relevansi ceramah (dakwah) dengan aktivitas pengamalan nilai-nilai ekonomi Islam. Subpertanyaannya adalah pendapat dan penilaian masyarakat tentang pengaruh dakwah pada perilaku masyarakat dalam transaksi ekonomi dan pengetahuan masyarakat tentang ekonomi Islam. Dari dua subpertanyaan ini diketahui bahwa 65 orang atau 43,3\%, menjawab baik, dan 42 orang atau $28 \%$ menjawab sangat baik, artinya menurut penilaian masyarakat sebenarnya terdapat pengaruh dakwah terhadap perilaku masyarakat dalam kegiatan ekonomi, namun masyarakat tidak begitu memahami nilai-nilai ekonomi Islam. Pemahaman seperti ini ditarik dari hasil analisis bahwa masih terdapat sebesar 38 
orang atau 25,3\% yang menjawab kurang baik, bahkan terdapat 5 orang atau 3,3\% yang menjawab tidak baik, dalam arti bahwa menurut mereka dakwah ini tidak begitu relevan dengan pengamalan nilai-nilai ekonomi Islam dalam bertransaksi.

Berdasarkan akumulasi jawaban yang diperoleh tentang variabel pengamalan nilai-nilai ekonomi Islam sebagaimana dalam tabel rekapitulasi frekuensi nomor 2 di atas dapat dijelaskan bahwa masyarakat melaksanakan nilai-nilai ekonomi Islam dalam kehidupan sehari-hari. Terbukti dari akumulasi jawaban masyarakat ditemukan 420 jawaban atau 46,7\% yang mengatakan pengamalan (aktualisasinya) baik, dan 154 jawaban atau 17, 1\% menjawab pengamalan (aktualisasinya) sangat baik. Tapi perlu diperhatikan bahwa masih terdapat angka sebesar 280 orang atau 31,1\% jawaban kurang baik, bahkan 46 jawaban atau 5,1\% menjelaskan pengamalan nilai-nilai ekonomi Islam di masyarakat tidak baik. Meskipun persentasenya cukup kecil dibandingkan dengan yang menjawab aktualisasi nilai-nilai ekonomi Islam pengamalannya baik, tetapi tentu persentase ini tetap menjadi indikasi masih terdapat masyarakat yang kurang mengaktualisasikan nilai-nilai ekonomi Islam dalam kehidupannya.

Untuk melengkapi dan memastikan besaran kontribusi dakwah terhadap aktualisasi nilai-nilai ekonomi Islam di masyarakat Melayu pedesaan Kecamatan Rambah Rokan Hulu dapat diketahui dengan analisis data kuantitif seperti telah dijelaskan sebelumnya.

Berdasarkan pada perhitungan dan analisis data yang dilakukan, diperoleh hasil akhir atau koefisien korelasi kontingensi sebesar 0,273 dan setelah dicari nilai Phi $\left.{ }^{(}\right)$ diperoleh harga sebesar 0,284. Selanjutnya harga phi $(\phi)$ tersebut dikonsultasikan dengan nilai $r$ product moment, dengan terlebih dahulu dicari $d f$ (degress of freedom) $=$ $\mathrm{N}-\mathrm{nr}=75-2=73$. Dengan $d f 73$ tidak ditemukan, maka digunakan df 70, diperoleh nilai $r$ product moment, 0,302 untuk level $1 \%$, dan 0,232 untuk level signifikansi $5 \%$. Dengan demikian harga phi $(\phi)$ lebih kecil dari $r$ tabel pada taraf signifikansi $1 \%$, meskipun terdapat sedikit kelebihan pada taraf signifikansi 5\%. Hasil ini menunjukkan bahwa pada level signifikansi 1\%, hipotesis kerja (Ha) ditolak, dan Ho diterima, sementara pada level 5\%, Ha diterima dan Ho ditolak, tapi tidak signifikan. Dilihat dari tingkat probabilitasnya, maka kondisi ini dapat dinyatakan pada level $1 \%$ atau pada tingkat keyakinan 99\% aktivitas dakwah belum berkontribusi terhadap aktualisasi nilai ekonomi Islam, tapi pada level 5\%, atau pada tingkat keyakinan 95\%, dapat diyakini bahwa dakwah memiliki kontribusi terhadap aktualisasi nilai-nilai ekonomi Islam oleh masyarakat Melayu di Rokan Hulu. Situasi ini dapat dimaknai masih terdapat kontribusi aktivitas dakwah dalam upaya aktualisasi nilai-nilai ekonomi Islam tapi kurang signifkan.

Dari hasil analisis data tersebut dapat diinterpretasikan bahwa masih terdapat kontribusi aktivitas dakwah dalam upaya aktualisasi nilai ekonomi Islam oleh etnis Melayu di daerah pedesaan Kecamatan Rambah. Dengan kata lain, pelaksanaan nilai- 
nilai ekonomi Islam di Rokan Hulu tidak banyak disebabkan atau dimotivasi oleh kegiatan dakwah yang terus-menerus dilakukan di tengah masyarakat.

Dari wawancara yang dilakukan terhadap mubalig, diketahui bahwa pemahaman masyarakat Melayu tentang ekonomi Islam tidak begitu banyak diperoleh dan ceramah (dakwah), karena mubalig tidak banyak yang memahami istilah ekonomi Islam. Nilainilai ekonomi Islam lebih banyak mereka tahu dari petuah melalui kata-kata bijak orang tua, misalnya pepatah tentang nilai ekonomi Islam: harta benda itu yang penting ialah berkahnya bukan jumlahnya. Kemudian lagi, harta yang diperoleh dengan jalan curang (tidak halal) akan mendatangkan bencana, mencari harta sekadar yang diperlukan, jangan sampai mati dalam keadaan berutang. Ini merupakan nilai-nilai ekonomi Islam yang jarang sekali disampaikan oleh mubalig dalam kegiatan dakwahnya. Nilai-nilai seperti ini secara psikologis menjadi alat dan mekanisme kontrol yang sangat efektif sebagai acuan perilaku dalam kegiatan ekonomi. Disamping itu, masyarakat juga lebih banyak memperoleh informasi tentang nilai-nilai dan kegiatan ekonomi Islam dari buku-buku dan orang tua yang menjadi tokoh dan panutan masyarakat setempat.

Terkait dengan aktualisasi nilai-nilai tersebut dalam kehidupan sehari-hari dari hasil observasi, wawancara, dan hasil angket diketahui bahwa nilai-nilai ekonomi Islam tersebut sebagian besar masih dilaksanakan oleh etnis Melayu, sebagaimana terdapat dalam sistem nilai masyarakat tersebut selama ini. Hal ini tentu tidak terlepas dari peran dan kontribusi dakwah yang dilakukan selama ini dalam melestarikan dan mewariskan nilai-nilai ekonomi tersebut oleh masyarakat dari generasi ke generasi berikutnya.

Dalam penelitian ini ditemukan kontribusi dakwah tersebut tidak terlalu signifikan. Terlepas dari diskursus tentang tinggi-rendahnya nilai signifikansi kontribusi dakwah terhadap aktualisasi nilai-nilai ekonomi Islam. Saat ini nilai ekonomi Islam masih eksis dan dapat ditemukan di masyarakat Melayu pedesaan Kecamatan Rambah. Pertama, Nilai Rabbaniyah (Nilai Ketuhanan/Tauhid) Kunci sistem ekonomi Islam terletak pada hubungan manusia dengan Tuhan (Rabb) penguasa alam semesta. Ekonomi Islam adalah ekonomi ilahiah karena berangkat dari Allah. Tujuan hakikatnya mencari rida Allah dan cara-cara yang dilakukan pun tidak bertentangan dengan syariat Allah. Kegiatan ekonomi Islam baik produksi, distribusi, konsumsi maupun transaksi harus dikaitkan dengan prinsip ketuhanan. Seluruh lapangan ekonomi diliputi oleh tauhid (QS. At-Taubah: 24).

Nilai Rabbaniyah ini tetap menjadi bagian penting dalam landasan budaya ekonomi Melayu di Pedesaan Rambah sesuai dengan identitas Melayu yang Islami. Nilai tauhid ini antara lain terekam dalam pepatah dan tradisi Melayu, harta benda itu yang penting ialah berkahnya bukan jumlahnya. Artinya tidak perlu harta banyak kalau diperoleh dengan jalan yang haram karena pasti tidak ada berkahnya yang didapat justru bencana.

Kedua, Nilai akhlak (moral) merupakan bagian penting dalam sistem ekonomi Islam dan nilai ini tetap menjadi bagian dari prinsip yang dipegang oleh masyarakat 
Melayu dalam usaha memenuhi kebutuhan hidupnya sehari-hari. Nilai akhlak ini telah dijadikan masyarakat sebagai fondasi penting di samping aspek teologis dalam membangun kehidupan. Dalam kegiatan-kegiatan ekonomi yang dilakukan oleh masyarakat Melayu tersebut nilai akhlak tetap dikedepankan dalam perilaku ekonomi mereka. Petuah tradisi yang diilhami oleh nilai ekonomi Islam seperti ungkapan harta yang diperoleh dengan jalan curang (tidak halal) akan mendatangkan bencana telah menjadi salah satu norma penting dalam kegiatan perilaku ekonomi masyarakat.

Ketiga, Nilai kemanusiaan dalam ekonomi Islam terhimpun dalam nilai kemerdekaan, kebebasan, persaudaraan, kasih sayang. Dalam wujud operasionalnya konsep-konsep ini tertuang dalam budaya dan tradisi Melayu seperti jangan curang, jangan menipu orang, tak boleh kikir, harus menyayangi fakir miskin, dan lain sebagainya. Nilai kemanusiaan ini dalam sistem ekonomi Islam didasari oleh prinsip keadilan (QS. Al-Baqarah: 165).

Keempat, Nilai pertengahan pada masyarakat Melayu sangat dominan dalam kegiatan ekonomi masyarakat. Prinsip keseimbangan (tawazun) yang menjadi fokus dalam ajaran Islam, telah menjadi bagian penting dalam transaksi ekonomi masyarakat. Salah satu ciri khas dalam masyarakat Melayu adalah, selalu hidup dan berada dalam keseimbangan antara terlalu kikir dan terlalu pemurah. Bagi masyarakat Melayu harta adalah pemberian Tuhan yang harus dimanfaatkan sebaik-baiknya, karena itu harta harus didapat, dan digunakan sesuai dengan perintah Tuhan.

Perlu disadari bahwa meski mengenalkan diri sebagai agama sehingga menyiratkan kesan ritual secara dominan, Islam sesungguhnya merupakan konsep ajaran yang utuh dan menyeluruh. Islam tidak meletakkan garis pemisah antara urusan dunia dan akhirat atau profan dan transenden untuk meletakkan keduanya secara dikotomis. Islam justru mengajarkan adanya keterkaitan antara keduanya sehingga tidak mungkin mengutamakan salah satu untuk meninggalkan yang lain. Islam juga tidak mengajarkan untuk mengutamakan satu aspek kehidupan dan mengabaikan yang lain di satu sisi. Oleh sebab itu, Islam tidak membenarkan penganutnya menjalankan ritual setiap saat dan di sisi lain mengabaikan kegiatan-kegiatan ekonomi. (Mu'min Rauf, 2011: 144).

Aktualisasi nilai-nilai ekonomi Islam seperti sifat kejujuran, keadilan, dan tidak menipu tetap menjadi bagian dari kehidupan ekonomi masyarakat etnis Melayu pedesaan. Sikap saling mengasihi dan menyayangi, tolong menolong, menyayangi fakir miskin, dan siap berbagi dengan orang lain sebagai wujud nilai kemanusiaan masih sangat kental di masyarakat perdesaan Melayu Rokan Hulu. Internalisasi Islam yang sangat merasuk dalam kehidupan, tradisi, dan pandangan dunia Melayu menyebabkan sampai saat ini masih banyak masyarakat etnis melayu pedesaan di Kecamatan Rambah yang enggan berurusan dengan bank konvensional untuk melakukan peminjaman dan menabung. Ini disebabkan bunga bank (dalam konsepsi Islam/masyarakat Melayu disebut riba) karena riba (bunga bank) dalam pengetahuan masyarakat yang telah 
diwariskan turun temurun hukumnya haram. Melalui resam (tradisi) telah diwariskan bahwa Islam tidak membenarkan melakukan transaksi ekonomi menggunakan riba. Namun demikian bukan berarti tidak ada orang Melayu yang menggunakan jasa bank konvensional. Ada juga masyarakat Melayu di pedesaan yang menggunakan jasa bank konvensional karena beberapa ustaz/mubalig ada yang berpendapat dan membolehkan bunga bank dengan alasan tertentu. Padahal, para dai adalah orang yang seharusnya menguasai fakta tentang masalah keumatan agar dapat memberikan pandangan Islam yang benar terkait permasalahan yang dihadapi umat (Mahmuddin, 2013: 101).

Dengan demikian, analisis ini dapat diakhiri dengan pernyataan bahwa aktivitas dakwah yang dilakukan secara kontinu di masyarakat pedesaan Kecamatan Rambah memiliki kontribusi terhadap aktualisasi nilai-nilai ekonomi Islam dalam berbagai kegiatan ekonomi masyarakat, meskipun tidak memiliki korelasi yang terlalu signifikan. Faktor penting yang diduga sebagai pemicu rendahnya taraf signfikansi tersebut adalah materi tentang ekonomi Islam sangat jarang dijadikan sebagai materi dakwah (ceramah) oleh ustaz/mubalig, kecuali materi yang bersifat praktis seperti infak, sedekah, dan zakat.

\section{Simpulan}

Dari hasil analisis dan pembahasan terhadap data penelitian, dapat disimpulkan bahwa aktivitas dakwah yang dilakukan kurang memberikan kontribusi yang positif dan signifikan terhadap aktualisasi nilai-nilai ekonomi Islam di masyarakat pedesaan Melayu Kecamatan Rambah Rokan Hulu. Oleh sebab itu, kemampuan aktualisasi nilainilai ekonomi Islam yang masih terdapat dalam berbagai kegiatan ekonomi masyarakat Melayu pedesaan Kecamatan Rambah lebih banyak bersumber dari pengetahuan dan pemahaman khazanah peradaban dan tradisi etnis Melayu. Ini karena nilai-nilai Islam yang memang sangat kental dalam masyarakat Melayu.

Nilai ekonomi Islam lebih dipahami dari tradisi dan nilai budaya Melayu daripada yang dipengaruhi oleh kegiatan dakwah yang secara rutin dilakukan. Kuatnya internalisasi nilai-nilai ekonomi Islam pada sebagian besar masyarakat Melay menyebabkan mereka enggan menggunakan jalur perbankan konvensional untuk membangun perekonomiannya. Ini disebabkan bank menerapkan prinsip bunga bank (riba). Temuan penelitian menginformasikan bahwa kurangnya kontribusi dakwah dalam aktualisasi nilai-nilai ekonomi Islam di masyarakat Melayu Rambah disebabkan oleh materi-materi dakwah tentang ekonomi Islam kurang banyak disampaikan oleh ustaz kecuali yang bersifat praktis seperti infak, sedekah, dan zakat.

\section{Referensi}

Anshori, M. I. (1984). Mujahid Dakwah, Bandung: Diponegoro.

Eriyanto (2014). Analisis Jaringan Komunikasi. Jakarta: Prenada Media Group. 
Hamidy, U.U. (1999). Islam dan Masyarakat Melayu di Riau. Pekanbaru: UIR Press.

Hatimah, H \& Kurniawan, R. (2017). Integrasi Dakwah dan Ekonomi Islam. Jurnal Al Qardh, 5 (1), 1-11.

Iskandar, E. (2017). Urgensi Sistem Pendidikan Ekonomi Islam Sejak Dini. Jurnal Sabilarrasyad, 2 (2), 251-263.

Kafie, J. (1993). Psikologi Dakwah, Surabaya: Penerbit Indah.

Mahmuddin. (2013). Strategi Dakwah terhadap Masyarakat Agraris. Jurnal Dakwah Tabligh, 14 (2), 101-113.

Puteh, M. J. (2001). Dakwah Tekstual dan Kontekstual. Yogyakarta: Pustaka Pelajar.

Rahman, A. (1992) Al-Qur'an dan Sumber Ilmu Pengetahuan/Quranic Science. Jakarta: Aneka Cipta.

Rauf, M. (2011). Relevansi Prinsip ekonomi Islam dalam Pembinaan Umat Islam Indonesia, Al-Iqtishad, 3 (1).

Romli, S. (2005). Metode dakwah. Jurnal Dakwah Risalah, 10 (2), 126-137.

Saleh, A.R, (1977). Manajemen Dakwah Islam. Jakarta: Bulan Bintang.

Saud, M. A. (1996). Garis-garis Besar Ekonorni Islam. Jakarta: Gema Insani Press. 